\title{
Examination of Relationship between Attachment Dimensions and Teaching Profession Attitudes of Preschool Pre-service Teachers in Turkey
}

\author{
Seda $\operatorname{Ata}^{1}$ \\ ${ }^{1}$ Assistant Professor, Department of Early Childhood Education, Mugla Sitki Kocman University, Mugla, Turkey \\ Correspondence: Seda Ata, Assistant Professor, Department of Early Childhood Education, Mugla Sitki Kocman \\ University, Mugla, Turkey.
}

Received: October 20, 2016

Accepted: November 7, $2016 \quad$ Online Published: November 10, 2016

doi:10.11114/jets.v4i12.1936

URL: http://dx.doi.org/10.11114/jets.v4i12.1936

\begin{abstract}
The aim of this research was to determine the relationship between attachment dimensions and Attitude towards Teaching Profession (love, harmony and value) of preschool pre-service teachers. The research data were collected using the Experiences in Close Relationships Questionnaire-Revised and Attitude Scale of Teaching Profession. In the study there were 123 preschool pre-service teachers who filled the questionnaire. Data were analyzed using Pearson's correlation analysis and multiple linear regression. The research results have revealed a significant relationship between attachment anxiety and love dimension, besides significant relationship between attachment avoidance and value dimension. The multiple linear regression analysis results have suggested that attachment anxiet predicts love dimension of attitude of teaching profession. And also attachment avoidance predicts value dimension of attitude of teaching profession. The findings obtained from the study were discussed in the light of the related literature and some suggestions were made for future researches.
\end{abstract}

Keywords: preschool pre-service teachers, attachment anxiety, attachment avoidance, attitudes towards teaching

\section{Introduction}

\subsection{Introduce the Problem}

Even though the attachment theory has focused on the relationship between baby-caregiver (mother), it is stated that this process continues from the cradle to the grave (Bowlby, 1979). Provided that the caregiver is an accessible and responding person, the feeling of trust develops; otherwise, in case he/she does not respond to or is not accessible in regard to attention and needs of the individual in need of care, the feeling of distrust emerges (Mikulincer and Shaver, 2005). The feeling of trust or distrust embeds into internal working models that affect individuals' cognitions, emotional experiences, and many situations such as search for intimacy (Collins, Guichard, Ford, \& Feeney, 2004; Mikulincer, Shaver, \& Pereg, 2003). These internal working models enable us to create cognitive templates about us and others in our social relationships and guide our social behaviors (e.g., Collins \& Read, 1994; Mikulincer \& Shaver, 2003; Shaver \& Mikulincer, 2002). With Bowlby defining attachment as being from the cradle to the grave and Ainsworth et al. (1978) taking the attachment theory to the empirical experimental platform, the theory was now based on sounder grounds. Later, results of several studies starting with Hazan and Shaver's (1987) study on romantic relationships for the first time have proved the importance of attachment relationships in adulthood (e.g., Collins \& Feeney, 2010; Fraley \& Shaver, 2000; Mikulincer \& Shaver, 2007; Pietromonaco \& Barrett, 2000; Simpson \& Rholes, 1994). In addition, it is argued on the basis of attachment system's effect on exploratory behaviors that attachment dimensions may have an impact on individuals' working life (Hazan \& Shaver, 1990; Mikulincer \& Shaver, 2007). The attachment theory suggests that secure attachment can cope with negative feelings by the effective use of internal sources; however, insecure attachment (anxiety and avoidance) is a risk factor in the ability to cope with negative feelings (Mikulincer, Shaver, \& Pereg, 2003).

Based on this, it is stated that secure attachment is positively related to deciding a certain career at workplace (Ketterson \& Blustein, 1997), exhibiting exploratory behaviors regarding the career (Littman-Ovadia, 2008), and the capacity of reconciling for workplace objectives and exhibiting harmonious behaviors at the workplace (Blustein, Prezioso, \& 
Schultheiss, 1995). It has been articulated in previous studies that securely attached individuals have higher levels of job satisfaction (Krauz, Bizman, \& Braslavsky, 2001; Sumer \& Knight, 2001). It has also been seen that secure attachment is in relation with effective career development in topics such as attention to choice of profession (Blustein, Walbridge, Friedlander, \& Palladino, 1991; Wolfe \& Betz, 2004), adaptation to university (Mattanah, Lopez, \& Govern, 2011), progress in profession (e.g., Vignoli, Croity-Belz, Chapeland, de Fillipis, \& Martine, 2005) professional self-efficacy (O'Brien, Friedman, Tipton, \& Linn, 2000), and choice of profession (Tokar,Withrow, Hall, \& Moradi, 2003; Vignoli, 2009). On the other hand, it has been found that insecure attachment is related to indecision on choice of profession (e.g., Downing \& Nauta, 2010; Tokar et al., 2003) and dysfunctional thoughts on profession (van Ecke, 2007). Professional negative emotions (anxiety and pessimism) play a partial intermediary role in the relationship between anxious attachment and choice of profession (Braunstein-Bercovitz, Benjamin, Asor, and Lev, 2012). As for the avoidance dimension of insecure attachment, it may have negative impacts on choice of profession (Downing \& Nauta, 2010) and doing research on professions (Littman-Ovadia, 2008).

Ronen and Mikiluncer (2009) stated in their study in which they examined the relationship between attachment dimensions and burnout that insecure attachment is related to developing a negative perception of team coherence and organizational justice. The relationship between attachment anxiety and attachment avoidance and high level of burnout and low level of job satisfaction has been proven by the research results (e.g., Hardy \& Barkham, 1994; Hazan \& Shaver, 1990; Pines, 2004; Ronen \& Baldwin, 2010; Ronen \& Mikulincer, 2009). In their study addressing the executive-employee relationship on the basis of attachment dimensions, Ronen and Mikiluncer (2012) found that executive's insufficient interest has a partial intermediary role in the relationship between insecure attachments of executives and employees' high level of burnout and low level of job satisfaction. Moreover, it was seen that employees' insecure attachments were in relationship with burnout and workplace dissatisfaction. It is thought that attachment dimensions (attachment anxiety and attachment avoidance) are related to low levels of organizational commitment, positive social behaviors and productive behaviors (Mikulincer \& Shaver, 2007).

It has also been seen that attachment anxiety and attachment avoidance is related to evaluating the group negatively. Attachment anxiety is in relationship with high-level exhibition of behavior of searching for both technical and emotional help (Richards \& Schat, 2011). Distrust and low levels of self values experienced by anxiously attached individuals may also affect their business relations as well as relationships in their private lives (Mikulincer \& Shaver, 2007). In addition, it is stated that anxious individuals do not believe that they are perceived by their colleagues as being worthless (Hazan \& Shaver, 1990) and they are concerned about the relationships at the workplace and their job performances (Hardy \& Barkham, 1994). It has been found that there is a negative relationship between attachment anxiety and the behavior of providing colleagues with technical support (Geller \& Bamberger, 2009). In general, it has been seen that attachment anxiety is related to low self-esteem (Collins \& Read, 1990; Hazan \& Shaver, 1987; Simpson, 1990) and the extreme expectation of being relieved by others (Shaver, Schachner, \& Mikulincer, 2005). Anxious individuals tend to perceive themselves as being worthless and misunderstood at the workplace (Hazan \& Shaver, 1990). Attachment anxiety is regarded as the cognitive confusion caused by doubting about self-value, being dependent on others, and reinforcement of negative emotions (Mikulincer \& Shaver, 2007). In a study performed by Henson and Scharfe (2011) with 230 university students, it was revealed that there is a negative relationship between attachment anxiety and behaviors of evaluating the course negatively. Whereas it is stated that anxious attachment is related to being indecisive about choosing a profession (BraunsteinBercovitz, Benjamin, Asor, \& Lev, 2012; Downing \& Nauta, 2010; Tokar et al., 2003), it has also been found as a result of a research that anxiously attached individuals are not necessarily indecisive about the choice of profession (van Ecke ,2007).

It has been stated that attachment avoidance is related to some negativities and continuance of the avoidance behavior in socio-emotional and functional behaviors (Rom and Mikulincer, 2003). Avoidant individuals have more positive perceptions of themselves than anxious individuals (Mikulincer, 1995). According to Hardy and Barkham (1994), avoidant individuals are more concerned about working hours and in more conflict with their colleagues. Moreover, avoidant individuals may have stronger intentions of quitting the job (Mikulincer and Shaver, 2007). Richards and Schat (2011) established that there is a relationship between attachment avoidance and low levels of helping technically and emotionally at workplace and high levels of exhibiting the behavior of keeping emotional behavior under control. Attachment avoidance is defined as the tendency to situations such as being uncomfortable in interpersonal relationships, hindering the emotions and being unsuccessful at managing negative situations (Mikulincer \& Shaver, 2007). In the study performed with 173 university students, Braunstein-Bercovitz et al (2012) found that attachment avoidance has an impact on choice of profession through the complete mediator role of self-criticism. In addition, she also stated that there is a significant relationship between self-criticism and indecision in choice of profession. There are research results showing that attachment avoidance is directly (van Ecke, 2007) and indirectly (Downing \& Nauta, 2010) related to choice of profession and they have no relationship between each other (Braunstein-Bercovitz et al., 2012). 
It is interesting that the studies performed by attachment researchers in lines of works such as military and private sector as well as the studies performed by educators on the basis of adult attachment are limited in numbers in general. Current studies on adult attachment provide extremely limited contextual information on teachers' professional life (Riley, 2009; Ata, 2010; Ata and Akman, 2016; Morris-Rothschild and Brassard, 2006). It is thought that attitudes of teacher candidates who go through a period during which theoretical and practical foundations of teaching profession are laid towards the teaching profession will have an impact on their professional life (Terzi and Tezci, 2007). Positive attitudes towards the teaching profession are associated with conditions such as being interested in the profession, loving children, being able to see the importance of education and teaching, etc. whereas negative attitudes are associated with conditions such as not liking children, not being able to improve oneself, and not being excited and willing, etc. Individuals having such attitudes are more likely to succeed by exhibiting the learning and teaching behaviors easily. On the other hand, negative attitudes associated with situations such as not liking children, not being able to improve oneself, and not being excited and willing may decrease the chance to succeed (Semerci and Semerci, 2004). It is especially thought that what attitudes teacher candidates of preschool, which is the basic step of the educational system, do have towards their professions will largely affect current practices. Based on the fact, the purpose of the research is to examine the relationship between preschool teacher candidates' attachment dimensions (attachment anxiety and attachment avoidance) and their teaching profession attitudes. To this end, answers to the following questions were sought for:

1. Is there a significant relationship between preschool teacher candidates' attachment dimensions and their teaching profession attitudes?

2. Do preschool teacher candidates' attachment dimensions predict their teaching profession attitudes?

\section{Method}

In this study, the relationship between attachment dimensions of preschool pre-service teachers and their attitude towards the profession of teaching was tested.

\subsection{Study Group}

The study group was formed with 150 preschool pre-service teachers in the 2013-2014 academic year at Hacettepe University. However, only 123 preschool pre-service teachers participated in the study. All of the participants were female. A majority of the participants, 72.6\%, were in the 20-25 age range.Data Collection ToolsThe research data was collected using the "Questionnaire", "Experiences in Close Relationships Questionnaire - Revised" and "Attitude Scale of Teaching Profession". Questionnaire

The first part of the questionnaire included questions concerning demographics of the participants such as age and gender.

\subsection{Experiences in Close Relationships Questionnaire}

Attachment dimensions were measured via the Turkish translation (Selçuk, Günaydın, Sümer, \& Uysal, 2005) of Experiences in Close Relationships (ECR-R) developed by Fraley et al., (2000) assessing the adult attachment anxiety and avoidance dimensions. The avoidance subscale (18 items; $\alpha=.88$, and .85 ; for wives and husbands, respectively) measures the extent of an individual's discomfort with closeness, dependence, and selfdisclosure (e.g., 'I am nervous when my spouse gets too close to me'). The anxiety subscale (18 items; $\alpha=.85$, and .83 ; for wives and husbands, respectively) refers to a strong need for closeness, fear of being abandoned, and rejection (e.g., 'I often worry that my spouse doesn't really love me'). Participants indicated their level of agreement with each item on a 5-point Likert (disagree-agree) scale. The mean scores of each dimension were calculated. Similar to previous studies on married couples (e.g., Rowe \& Carnelley, 2003), items were changed slightly by replacing the term 'your partner' with 'your husband' or 'your wife' to make them appropriate for the marital context.

\subsection{Attitude Scale of Teaching Profession}

In the research, a scale,called "Attitude Scale of Teaching Profession" developed by Cetin (2006) and published in Gazi University Journal of Industrial Arts Education Faculty in 2006 with its validity and reliability tests having been conducted,was used. The 5 likert-type scale, graded as "Strongly Agree - Agree - Undecided - Disagree - Strongly Disagree", involved 35 items on three basic themes (love, value, harmony). The total alpha value of the scale was .95.

\subsection{Procedure}

After informing the preschool pre-service teachers about the aim of the research, the questionnaire was administered to 150 participants collectively in their classrooms at the end of spring term of 2013-2014 academic period. The questionnaire was revised before data analysis, and the forms of three participants were eliminated from the dataset because they had incomplete information. As a consequence, the data collected from 123 participants were used for 
analysis. Pearson's Correlation analysis and linear regression were used for data analysis.

\section{Results and Discussions}

To examine the relationship between preschool teacher candidates' attachment dimensions (attachment anxiety and attachment avoidance) and their teaching profession attitudes, a correlation analysis was performed and Pearson's Correlation Coefficient was obtained.

Table 1. Correlation among variables (attachment dimensions and attitude of teaching professions)

\begin{tabular}{llllll}
\hline & & Love & Value & Harmony & $\begin{array}{l}\text { Total } \\
\text { Score }\end{array}$ \\
\hline Attachment anxiety & $\mathrm{r}$ & $.37^{* *}$ & .01 & -.08 & $.28^{* *}$ \\
& $\mathrm{p}$ & .00 & .08 & .03 & .00 \\
Attachment avoidance & $\mathrm{r}$ & .01 & $.22^{*}$ & .13 & .08 \\
& $\mathrm{p}$ & .08 & .01 & .14 & .03
\end{tabular}

According to the correlation analysis results in Table 1, attachment anxiety has a positive, moderate-level relationship with love $(\mathrm{r}=.37 \mathrm{p}<.01)$ and a positive, low-level relationship with total attitude scale $(\mathrm{r}=.28, \mathrm{p}<.01)$. Attachment avoidance has a positive, low-level relationship only with the sub-dimension of value of teaching profession $(r=.22$, $\mathrm{p}<.05)$ whereas there is no significant relationship between attachment avoidance and other sub-dimensions.

Next, a linear regression analysis was performed to examine the relationship between attachment dimensions (attachment anxiety and attachment avoidance) and sub-dimensions of the attitude scale of teaching profession. In the first stage, three regression models (1-2-3) were established, in which attachment avoidance is the independent variable, and the sub-dimensions of the attitude scale of teaching profession are dependent variables, and it was investigated to what extent attachment avoidance is predicted by love, value and harmony sub-dimensions respectively. Likewise, in the models in which attachment anxiety was accepted as the independent variable (4-5-6), it was investigated to what extent the independent variable predicts love, value and harmony sub-dimensions respectively.

\begin{tabular}{|c|c|c|c|c|c|c|}
\hline Model & $\begin{array}{l}\text { Dependent } \\
\text { Variables }\end{array}$ & Independent Variables & $R^{2}$ & $\mathrm{P}_{\text {Model }}$ & ßo & $(\beta)$ \\
\hline 1 & Love & Attachment avoidance & 0 & 0,882 & $71,641 *$ & $\begin{array}{l}0,014 \\
(p=0,882)\end{array}$ \\
\hline 2 & Value & Attachment avoidance & 0,05 & $0,014^{*}$ & 6,923 & $\begin{array}{l}0,224^{*} \\
(p=0,014)\end{array}$ \\
\hline 3 & Harmony & Attachment avoidance & 0,017 & 0,148 & 5,563 & $\begin{array}{l}0,132 \\
(\mathrm{p}=0,148)\end{array}$ \\
\hline 4 & Love & Attachment anxiety & 0,143 & $0,000^{*}$ & $-103,734^{*}$ & $\begin{array}{l}0,378^{*} \\
(\mathrm{p}=0,000)\end{array}$ \\
\hline 5 & Value & Attachment anxiety & 0 & 0,843 & 27,051 & $\begin{array}{l}0,018^{*} \\
(\mathrm{p}=0,843)\end{array}$ \\
\hline 6 & Harmony & Attachment anxiety & 0,008 & 0,339 & $23,624 *$ & $\begin{array}{l}-0,088 \\
(p=0,339)\end{array}$ \\
\hline
\end{tabular}

According to the regression analysis results in Table 2, the models 2 and 4 are statistically significant. In other words, the value sub-dimension is predicted by attachment avoidance and the love sub-dimension is predicted by attachment anxiety $(\mathrm{p}<.05)$ whereas attachment avoidance and attachment anxiety do not predict other sub-dimensions $(\mathrm{p}<.05)$. As for the model content and results for significant models, it is seen that scores of attachment avoidance explain 5\% of total variance for model $2[\mathrm{~F}(2.507): 13.55 ; \mathrm{p}<.05]$. It was found for model 5 that attachment anxiety explains $14.3 \%$ of love sub-dimension of teaching profession attitudes [F(2.507): 13.55; $\mathrm{p}<.05]$. When considering the inter-variable relationship directions, attachment avoidance predicts value sub-dimension of teaching profession attitudes and attachment anxiety predicts love sub-dimension of teaching profession attitudes positively.

It was examined in the research how preschool teacher candidates' attachment dimensions are related to their teaching profession attitudes and to what extent their attachment dimensions predict their teaching profession attitudes. According to the findings obtained, there is a positively significant relationship between teacher candidates' attachment 
anxiety scores and the love sub-dimension of teaching profession attitudes and the teaching profession attitudes (total score). It can be said that this finding is in parallel with the findings of the research conducted by Henson and Scharfe (2011) which revealed a negative relationship between university students' attachment anxiety and their scores of evaluating the course negatively. In other words, they may think that they will give the love, which they did not for their selves, for the profession they are yet to start to perform in the attitude dimension.

It was seen that there is a positive, low-level, significant relationship between attachment avoidance and the value sub-dimension of teacher candidates' teaching profession attitudes. It can be also said that research results showing that attachment avoidance causes individuals to avoid emotion-based approaches at workplace and give less importance to interpersonal relationships (Rom and Mikulincer, 2003; Mikulincer \& Shaver, 2007) coincide with the current finding of the study. Another finding obtained in the research is that attachment avoidance explains 5\% of the value sub-dimension. This finding can be found to be interesting in terms of the related literature. In the related literature, there are results achieved which show that attachment avoidance is rather related to certain interpersonal problems at workplace (Hardy \& Barkham, 1994) as well as those showing that it is also related to variables such as choice of profession and professional progress (van Ecke, 2007; Downing \& Nauta, 2010).

Another finding is that attachment anxiety makes an important contribution to the prediction of the love sub-dimension of the teaching profession attitudes. Accordingly, attachment anxiety explains $14.3 \%$ of the love sub-dimension. It can be concluded from this finding that attachment anxiety is related to individuals' power of emotional interpretation of the task (Hazan \& Shaver, 1990; Hardy \& Barkham, 1994). The sensitivity to these emotional messages and the effort of obtaining can be explained by the willingness to develop positive attitude towards the profession. Yet, according to the related literature, attachment anxiety is positively related to the intention of quitting the job and burnout and negatively related to job satisfaction (Ronen \& Baldwin, 2010; Ronen \& Mikulincer, 2009). In this context, it can be said that this finding is not supported by current research results in a sense.

\section{Recommendations}

According to the result of the study, it is seen that the attachment dimensions of the preschool pre-service teachers and teaching profession attitudes are related with each other. It was determined that the attachment avoidance is the predictor of the value sub-dimensions of the teaching profession attitude and attachment anxiety is the predictor of the love sub-dimensions of the teaching profession attitude of the preschool pre-service teachers.

As attachment orientation could be seen as comprehensive source for explaining human behavior, it may provide useful to focus on this teaching profession attitude (pre-service teacher) not only as a source of information that contributes to predicting performance, but also as a focal area for management development that may enhance performance at work. Findings of this study have potential practical significance in terms of using attachment orientation at professional attitude, besides importantly, in terms of using the theory to inform such as development of professional identity. Based on attachment dimensions, understanding teaching profession attitudes could assist early childhood teacher education program makers with decision concerning development of professional identity We hope that the results of this study will garner sufficient interest in attachment researchers to generate further investigations into the function of attachment at work.

There are some limitations to the research. The first one is that the data obtained were collected only on the basis of self-report. The second one is that the research was conducted only with preschool teacher candidates. Some recommendations were made in the light of these limitations. It can be recommended that the sample chosen in this study can be chosen from teacher candidates who are attending at all departments of the faculties of education. Including teacher candidates of different departments in the research will allow for a larger sample. As for the related literature in general, research studies can be performed to obtain certain demographics which are found to be related to teaching profession attitudes. In addition, research studies can be performed to investigate the relationship between teacher candidates' and teachers' attachment dimensions and both professional performances and job satisfactions.

\section{References}

Ainsworth, M. S., Blehar, M. C., Waters, E., \& Wall, 5. (1978). Patterns of attachment: A psychological study of the Strange Situation. Hillsdale, NJ: Erlbau

Ata, S. (2010). Okul öncesi öğretmenlerinin bağlanma stilleri, duygusal zeka düzeyleri ve empati eğilimlerinin incelenmesi. Unpublished master thesis, Muğla University, Muğla.

Ata, S., \& Akman, B.,(2016). The Investigation of The Relationship Among Attachment Dimensions, Classroom Management Profiles and TeacherFamily Relationships. Elementary Education Online, 15(3), 820-837.

Blustein, D. L., Prezioso, M. S., \& Schultheiss, D. P. (1995). Attachment theory and career development: Current status and future directions. The Counseling Psychologist, 23, 416-432. http://dx.doi.org/10.1177/0011000095233002 
Blustein, D. L., Walbridge, M. M., Friedlander, M. L., \& Palladino, D. E. (1991). Contributions of psychological separation, and parental attachment to the career development process. Journal of Counseling Psychology, 38, 39-50. http://dx.doi.org/10.1037/0022-0167.38.1.39

Bowlby, J. (1979). The making and breaking of affectional bonds. London: Tavistock.

Braunstein-Bercovitz, H., Benjamin, B. A., Asor, S., \& Lev, M. (2012). Insecure attachment and career indecision: Mediating effects of anxiety and pessimism. Journal of Vocational Behavior, 81, 236-244. http://dx.doi.org/10.1016/j.jvb.2012.07.009

Çetin, Ş. (2006). Öğretmenlik mesleği tutum ölçeğinin geliştirilmesi (Geçerlik ve güvenirlik çalışması). Gazi Üniversitesi Endüstriyel Sanatlar Eğitim Fakültesi Dergisi, 18, 28-37.

Collins, N. L., \& Feeney, B. C. (2010). An attachment theoretical perspective on social support dynamics in couples: Normative processes and individual differences. In K. Sullivan \& J. Davila (Eds.), Support processes in intimate relationships (pp. 89-120). New York, NY: Oxford University Press. http://dx.doi.org/10.1093/acprof:oso/9780195380170.003.0004

Collins, N. L., \& Read, S. J. (1990). Adult attachment, working models, and relationship quality in dating couples. Journal of Personality and Social Psychology, 58(4), 644-663. http://dx.doi.org/10.1037/0022-3514.58.4.644

Collins, N. L., \& Read, S. J. (1994). Cognitive representations of attachment: The structure and function of working models. In K. Bartholomew \& D. Perlman (Eds.), Attachment processes in adulthood (pp. 53-92). London: Jessica Kingsley.

Collins, N. L., Guichard, A. C., Ford, M. B., \& Feeney, B. C. (2004). Working models of attachment: New developments and emerging themes. In W. S. Rholes \& J. A. Simpson (Eds.), Adult attachment: Theory, research, and clinical implications (pp. 196-239). New York: Guilford Press.

Downing, M. H., \& Nauta, M. M. (2010). Separation-individuation, exploration, and identity diffusion as mediators of the relationship between attachment and career indecision. Journal of Career Development, 36(3), 207-227. http://dx.doi.org/10.1177/0894845309345848

Fraley, R. C., \& Shaver, P. R. (2000). Adult romantic attachment: Theoretical developments, emerging controversies, and unanswered questions. Review of General Psychology, 4, 132-154. http://dx.doi.org/10.1037/1089-2680.4.2.132

Geller, D., \& Bamberger, P. (2009). Bringing attachment and anxiety to the job: attachment style and instrumental helping behavior among co-workers. Human Relations, 62, 1803-1827. http://dx.doi.org/10.1177/0018726709337524

Hardy, G., \& Barkman, M. (1994). The relationship between interpersonal attachment styles and work difficulties. Human Relations, 47, 263-281. http://dx.doi.org/10.1177/001872679404700302

Hazan, C., \& P.R. Shaver (1987). Romantic love conceptualized as an attachment process. Journal of Personality and Social Psychology, 52, 511-524. http://dx.doi.org/10.1037/0022-3514.52.3.511

Hazan, C., \& Shaver, P. (1990). Love and work: an attachment-theoretical perspective. Journal of Personality and Social Psycholog, 59, 270-280. http://dx.doi.org/10.1037/0022-3514.59.2.270

Henson, A., \& Scharfe, E. (2011). Influence of attachment representations on undergraduate course evaluations. Teaching of Psychology, 38, 106-109. http://dx.doi.org/10.1177/0098628311401582

Ketterson, T. U., \& Blustein, D. L. (1997). Attachment relationships and the career exploration process. The Career Development Quarterly, 46, 167-178. http://dx.doi.org/10.1002/j.2161-0045.1997.tb01003.x

Krausz, M., Bizman, A., \& Braslavsky, D. (2001). Effects of attachment style on preferences for and satisfaction with different employment contracts: An exploratory study. Journal of Business and Psychology, 16, 299-316. http://dx.doi.org/10.1023/A:1011169419048

Littman-Ovadia, H. (2008). The effect of client attachment style and counselor functioning on career exploration. Journal of Vocational Behavior, 73, 434-439. http://dx.doi.org/10.1016/j.jvb.2008.08.004

Mattanah, J. F., Lopez, F. G., \& Govern, J. M. (2011). The contributions of parental attachment bonds to college student development and adjustment: A meta-analytic review. Journal of Counselling Psychology, 58(4), 565-596. http://dx.doi.org/10.1037/a0024635

Mikulincer, M. (1995). Attachment style and the mental representation of the self. Journal of Personality and Social Psychology, 69, 1203-1215. http://dx.doi.org/10.1037/0022-3514.69.6.1203 
Mikulincer, M., \& Shaver, P. R. (2003). The attachment behavioral system in adulthood: Activation, psychodynamics, and interpersonal processes. In M. Zanna (Ed.), Advances in experimental social psychology (Vol. 35). New York: Academic Press.

Mikulincer, M., \& Shaver, P. R. (2005). Attachment theory and emotions in close relationships: Exploring the attachment-related dynamics of emotional reactions to relational events. Personal Relationships, 12, 149-168. http://dx.doi.org/10.1111/j.1350-4126.2005.00108.x

Mikulincer, M., \& Shaver, P. R. (2007). Attachment in adulthood : Structure, dynamics, and change. New York, NY: Guilford Press.

Mikulincer, M., Shaver, P. R., \& Pereg, D. (2003). Attachment theory and affect regulation: The dynamics, development, and cognitive consequences of attachment-related strategies. Motivation and Emotion, 27(2), 77-102. http://dx.doi.org/10.1023/A:1024515519160

Morris-Rothschild, B., \& Brassard, M. R. (2006). Teachers' conflict managment styles: The role of attachment styles and classroom managment efficacy. Journal of School Psychology, 44(2), 105-121. http://dx.doi.org/10.1016/j.jsp.2006.01.004

O‘Brien, K. M., Friedman, S. M., Tipton, L. C., \& Linn, S. G. (2000). Attachment, separation, and women`s vocational development: A longitudinal analysis. Journal of Counseling Psychology, 47(3), 301-315. http://dx.doi.org/10.1037/0022-0167.47.3.301

Pietromonaco, P. R., \& Barrett, L. F. (2000). Internal working models: What do we really know about the self in relation to others? Review of General Psychology, 4, 155-175. http://dx.doi.org/10.1037/1089-2680.4.2.155

Pines, A. M. (2004). Adult attachment styles and their relationship to burnout: A preliminary, cross-cultural investigation. Work \& Stress, 18, 66-80. http://dx.doi.org/10.1080/02678370310001645025

Richards, D. A., \& Schat, A. C. 2011. Attachment at (not to) work: Applying attachment theory to explain individual behavior in organizations. Journal of Applied Psychology, 96, 169-182. http://dx.doi.org/10.1037/a0020372

Riley, P. (2009). An adult attachment perspective on the student-teacher relationship and classroom management difficulties. Teaching and Teacher Education, 25(5), 626-635. http://dx.doi.org/10.1016/j.tate.2008.11.018

Rom, E., \& Mikulincer, M. (2003). Attachment theory and group processes: The association between attachment style and group-related representation, goals, memories, and functioning. Journal of Personality and Social Psychology, 84, 1220-1235. http://dx.doi.org/10.1037/0022-3514.84.6.1220

Ronen, S., \& Baldwin, M. W. (2010). Hypersensitivity to social rejection and perceived stress as mediators between attachment anxiety and future burnout: A prospective analysis. Applied Psychology, 59, 380-403. http://dx.doi.org/10.1111/j.1464-0597.2009.00404.x

Ronen, S., \& Mikulincer, M. (2009). Attachment orientations and job burnout: the mediating role of team cohesion and organizational fairness. Journal of Social and Personal Relationships, 26, 549-567. http://dx.doi.org/10.1177/0265407509347930

Ronen, S., \& Mikulincer, M. (2012). Predicting employees' satisfaction and burnout from managers' attachment and caregiving orientations. European Journal of Work and Organizational Psychology, 21, 828-849. http://dx.doi.org/10.1080/1359432X.2011.595561

Rowe, A. C., \& Carnelley, K. B. (2003). Attachment style differences in the processing of attachment-relevant information: Primed-style effects on recall, interpersonal expectations, and affect. Personal Relationships, 10, 59-76. http://dx.doi.org/10.1111/1475-6811.00036

Semerci, N., \& Semerci, Ç. (2004). Türkiye'de öğretmenlik tutumları. Fırat Üniversitesi Sosyal Bilimler Dergisi, 14(1), 137-146.

Shaver, P. R., \& Mikulincer, M. (2002). Attachment-related psychodynamics. Attachment and Human Development, 4 , 133-161. http://dx.doi.org/10.1080/14616730210154171

Shaver, P. R., Schachner, D. A., \& Mikulincer, M. (2005). Attachment style, excessive reassurance seeking, relationship processes, and depression. Personality and Social Psychology Bulletin, 31(3), 343-359. http://dx.doi.org/10.1177/0146167204271709

Simpson, J. (1990). Influence of attachment styles on romantic relationships. Journal of Personality and Social Psychology, 59, 971-980. http://dx.doi.org/10.1037/0022-3514.59.5.971 
Simpson, J. A., \& Rholes, W. S. (1994). Stress and secure base relationships in adulthood. In K. Bartholomew \& D. Perlman (Eds.), Attachment processes in adulthood (pp. 181-204). London: Jessica Kingsley.

Sumer, H. C., \& Knight, P. (2001). How do people with different attachment styles balance work and family? A personality perspective on the work-family linkage. Journal of Applied Psychology, 86, 653-663. http://dx.doi.org/10.1037/0021-9010.86.4.653

Terzi, A. R., \& Tezci, E. (2007). Necatibey Eğitim Fakültesi öğrencilerinin öğretmenlik mesleğine ilişkin tutumları. Kuram ve Uygulamada Eğitim Yönetimi, 52, 593-614.

Tokar, D. M., Withrow, J. R., Hall, R. J., \& Moradi, B. (2003). Psychological separation, attachment security, vocational self-concept crystallization, and career indecision: A structural equation analysis. Journal of Counseling Psychology, 50, 3-19. http://dx.doi.org/10.1037/0022-0167.50.1.3

van Ecke, Y. (2007). Attachment style and dysfunctional career thoughts: How attachment style can affect the career counseling process. The Career Development Quarterly, 55, 339-350. http://dx.doi.org/10.1002/j.2161-0045.2007.tb00088.x

Vignoli, E. (2009). Inter-relationships among attachment to mother and father, selfesteem, and career indecision. Journal of Vocational Behavior, 75, 91-99. http://dx.doi.org/10.1016/j.jvb.2009.04.007

Vignoli, E., Croity-Belz, S., Chapeland, V., de Fillipis, A. \& Martine, G. (2005). Career exploration in adolescents: The role of anxiety, attachment, and parenting style. Journal of Vocational Behavior, 67, 153-168. http://dx.doi.org/10.1016/j.jvb.2004.08.006

Wolfe, J. B., \& Betz, N. E. (2004). The relationship of attachment variables to career decision-making self-efficacy and fear commitment. The Career Development Quarterly, 52, 363-369. http://dx.doi.org/10.1002/j.2161-0045.2004.tb00952.x 